

DOI: http://dx.doi.org/10.4995/LC2015.2015.1547

\title{
Le Corbusier's early urban studies as source of experiential architectural knowledge
}

\author{
C. Schnoor
}

Unitec Institute of Technology, Auckland, New Zealand

\begin{abstract}
In the year between April 1910 and March 1911 Le Corbusier - then Charles-Edouard Jeanneret - composed maybe the most comprehensive piece of writing of his career: a manuscript entitled "La construction des villes" which took on to systematically investigate the architectural elements that the city is made from. Taking Camillo Sitte's Der Städte-Bau nach seinen künstlerischen Grundsätzen of 1889 as his intellectual starting point, Jeanneret developed a complex and convincing thesis within several months, however never published it himself. One of the topics that appear throughout Jeanneret's manuscript is the quality of space as enclosure. This paper takes this observation as a starting point to ask how the manuscript that was put aside after March 1911 (and only shortly picked up again by Jeanneret in 1915) may have influenced Le Corbusier's architectural thinking. In order to achieve this, the chapter "The Illusion of the Plan" from Vers une architecture is investigated as a link between La construction des villes and Le Corbusier's houses. Finally, the Maison La Roche-Jeanneret and the Villa Savoye are read as buildings that very strongly incorporate aspects of thinking urban space in a way that way that closely relates to his studies back in 1910.
\end{abstract}

Keywords: La construction des villes; Städtebau; urban space; architectural space; Maison La Roche-Jeanneret; Villa Savoye.

\section{Introduction: The space of Le Corbusier's house designs and La construction des villes}

The well-known opening lines of Le Corbusier's Urbanisme contain a strong rebuttal of his earlier investigations of urban design. He suggests that he had been led on a false path by Camillo Sitte's ideas of a "sentimental past on a small and pretty scale, like the little wayside flowers", , in fact that it had been the path of the pack-donkey who meanders - instead of man's direction who walks in a straight line: “The Pack-Donkey's Way has been made into a religion. The movement arose in Germany as a result of the book by Camillo Sitte on town-planning, a most wilful piece of work; a glorification of the curved line and a specious demonstration of its unrivalled beauties $" 2$.

For the informed reader it is clear that Le Corbusier criticizes himself for being the pack-donkey, for following the winding path - and that he prompts himself to now walk in a straight line. But although he evokes the impression that his studies of Sitte and other urban design authors had been a waste of time, Le Corbusier knew better. He had, over the period of about a year from April 1910 to March 1911, composed a manuscript of astonishing clarity and rigour on questions of urban design, called La construction des villes, based on Camillo Sitte's book and on many other writings.

In my own research on La construction des villes, now more than ten years ago, I saw the first task in clarifying what Le Corbusier had really said - and to trace his writing back to his own sources, while attempting to identify

\footnotetext{
${ }^{1}$ Le Corbusier, The City of To-Morrow and its Planning, transl. Frederick Etchells (New York: Parson and Clarke, 1929), p. XXV. Originally published as Urbanisme. Paris: Crès, 1925.

${ }^{2}$ Le Corbusier, The City of To-Morrow, p. 8.
} 
his positions on these urban questions back in 1910 (the period which he speaks so condescendingly about in 1925). In Urbanisme, Le Corbusier suggests that he put everything to the side that he had read and erroneously believed in 1910. This paper therefore undertakes to take the knowledge gained from our study of Le Corbusier's urban design education a step further and to ask how it might have not been put to the side, despite his strong argument to the contrary, but how much and in which way his own knowledge, gained from the intense study of German language urban design literature and the direct experience of towns and cities at first hand was able to shape his formation as an architect. This can only be done in sketch format here but it might act as a useful starting point for further investigations. This paper thus follows Stanislaus von Moos' question in his foreword to the German/French edition of La construction des villes: "What happened to the text, after it had been shelved for the time being, respectively had been recast into the form of Urbanisme, which, in terms of its content, was mostly distorted into its contrary?"3

\section{The space of Le Corbusier's houses and La construction des villes}

With his unfinished manuscript "La construction des villes", Le Corbusier - still Charles-Edouard Jeanneret at that time - undertook an immense piece of writing - and learning - in 1910/11. ${ }^{4}$ He developed, probably more unwittingly than planned, a veritable treatise on urban design that, had it been published, would have added worthily to the contemporary writings on urban theory ${ }^{5}$. Requested by his teacher Charles L'Eplattenier, Jeanneret's task was to develop an argument for the aesthetic, or architectural reconsideration of the layout and organisation of his hometown La Chaux-de-Fonds which was to host the Assemblée générale des délégués de l'Union des villes suisses, scheduled to take place on 24 and 25 September 1910. But instead of providing a text for this convention he began to develop what might, under different circumstances, have become his academic thesis. He collected material, read about eighty books and journal articles, translated texts from German, wrote chapters and had about 600 pages of chapter texts and material ready by early 1911 - but no text for the September meeting in La Chaux-de-Fonds. In the end, L'Eplattenier published his own text. ${ }^{6}$ After abandoning the manuscript in early 1911, Jeanneret briefly took up work on it again in 1915, when he researched, in the Bibliothèques Nationales in Paris, further material for the intended book. But he never incorporated this material into the already written body of chapters. ${ }^{7}$

In his foreword to the first complete edition of La construction des villes, Stanislaus von Moos described it as a Steinbruch - a quarry - of Le Corbusier's work. ${ }^{8}$ And indeed, it is. Since he so meticulously put together his thesis, we can follow his intellectual, literary workmanship almost step by step from reading to note-taking to

\footnotetext{
3 "Was geschah mit dem Text, nachdem er fürs Erste ad acta gelegt bzw. in die sachlich mindestens über weite Strecken ins Gegenteil verdrehte Form von Urbanisme umgegossen worden war?" Stanislaus von Moos, "Vorwort. Im Steinbruch der Vormoderne", In Christoph Schnoor (ed.), La Construction des villes. Le Corbusiers erstes städtebauliches Traktat von 1910/11 (Zurich: gta, 2008), p. 13. Translation by author.

${ }^{4}$ Christoph Schnoor (ed.), La Construction des villes. Le Corbusiers erstes städtebauliches Traktat von 1910/11 (Zurich: gta, 2008).

${ }^{5}$ A closer comparison of La construction des villes with the Handbuch des Städtebaues by Cornelius Gurlitt, written in 1914 but only published in 1920 (Berlin: Architekturverlag Der Zirkel), reveals a surprising closeness in structure and argument.

${ }^{6}$ Charles L'Eplattenier, "L'esthétique des villes", in [Résumé de l'intervention de Charles L'Eplattenier à l'] Assemblée générale des délégués de l'Union des villes suisses réunis à la Chaux-de-Fonds à l'Hôtel de Ville, les 24 et 25 septembre 1910, Compte-rendu des délibérations de l'assemblée générale des délégués de l'union des villes suisses, 1910 ; Beilage zum schweizerischen Zentralblatt für Staats- und Gemeinde-Verwaltung 11 (1910), p. 24-31.

${ }^{7}$ It was Marc Albert Emery who published a first, albeit incomplete, edition of La construction des villes in 1992: Marc Albert Emery, Charles-Edouard Jeanneret, La Construction des villes (Lausanne: L:Age d'Homme, 1992).

${ }^{8}$ Von Moos, "Im Steinbruch der Vormoderne", p. 13.
} 
composing text. But this is only one aspect of the 'quarry' quality of La construction des villes. This manuscript holds a multitude of clues and suggestions for explaining Le Corbusier's later work.

Jeanneret studied recent German language theories of urban design, under the German term Städtebau (which translates into French as construction des villes). This was first promoted by architect Camillo Sitte in Vienna, whose volume Der Städte-Bau nach seinen künstlerischen Grundsätzen of $1889^{9}$ had been both popular as a piece of writing and influential in terms of developing the new discipline of designing cities. Sitte demanded to develop cities in a way that re-connected to the best historical periods of city-building, and thus to learn from old masters. However, Sitte did not study famous architects' works in order to come to an understanding of cities, instead he travelled, surveyed historic towns and cities, mostly in Italy and Germany, and derived his conclusions in a more phenomenological way than by arguing historically. Sitte's idea of a City Planning according to Artistic Principles ${ }^{10}$, taken up in German cities, was understood not so much as engineering or technical 'planning' but as a deeply architectural task and as such of vivid interest for Jeanneret who used Sitte as a starting point but extended his reading far beyond Sitte.

Rather than investigating in detail the content of La construction des villes ${ }^{11}$, this paper attempts to show how Le Corbusier's urban studies of 1910/11 did not just lay the foundations of his later urban design theory and practice but how they may have provided essential lessons on the design of architecture by his reading on - and grappling with - the form, structure and passer-by's perception of urban space. The paper argues that this substantially aided Le Corbusier's deep understanding of architecture, of architectural rhythm, space, proportion and circulation, not least the promenade architecturale. The paper will indicate how Jeanneret understood urban situations with the sense of spatial volume, of Raum, in mind ${ }^{12}$, and then compare elements of his 1910 writing to a chapter from Vers une architecture and investigate a few selected houses of the 1920s in order to demonstrate how aspects of La construction des villes seem to have aided Le Corbusier's architecture to evolve.

Why should we attempt to locate Jeanneret's urban research in his later houses - and not search for continuity between La construction des villes and Urbanisme? One answer is: this will be done elsewhere ${ }^{13}$; but more importantly, there is very little that, in an experiential sense, connects the spatial density and complex quality of Le Corbusier's houses with his (grand) urban designs. This paper now offers an answer to that problem by suggesting that, while of course elements of his research for La construction des villes went into the making of Urbanisme, another main (indirect?) outcome of this research is the quality of his houses. In an Albertian sense: the house is a small city.

\subsection{In La construction des villes, the notion of space as volume is ever-present}

Over a period of about seven months from April to November 1910 - mostly in Munich, with a journey to Berlin and (editorial) summer holidays in La Chaux-de-Fonds - Jeanneret incessantly read and took notes, translated excerpts, wrote chapters. Camillo Sitte was the intellectual starting point [Fig. 1] but by no means the only book he read. It has been possible to establish a bibliography of book titles and journal papers which Jeanneret read

\footnotetext{
${ }^{9}$ Camillo Sitte, Der Städte-Bau nach seinen künstlerischen Grundsätzen (Vienna: Graeser, 1889).

${ }^{10}$ This is the English title given to Sitte's book: Camillo Sitte, City Planning According to Artistic Principles, transl. George Collins and Christiane Crasemann-Collins (New York: Random House, 1965).

${ }^{11}$ This can be done through the forthcoming English edition; translated by Kim Sanderson, London: Ashgate, ca. 2016.

${ }^{12}$ Christoph Schnoor, "Le Raum dans La construction des villes de Le Corbusier. Une traduction aux multiples strates linguistiques et culturelles”, in Jean-Sébastien Cluzel (ed.), Traduire l'architecture (Paris 2015), pp. 120-29.

${ }^{13}$ Christoph Schnoor, "Le Corbusier and the Influence of Classicist Urban History", forthcoming in Armando Rabaça (ed.), Le Corbusier: History and Tradition (University of Coimbra, 2016).
} 
and worked with in 1910 that contains ca. 80 titles. ${ }^{14}$ All in all, while instigated by L'Eplattenier, this was nevertheless a thoroughly self-directed introduction into the new area of Städtebau ${ }^{15}$. Chapter by chapter, Jeanneret established what one could call a treatise of Städtebau questions, systematically investigating topics such as roads, perimeter blocks, public squares, parks, and applying his newly gained knowledge to his hometown, La Chaux-de-Fonds.

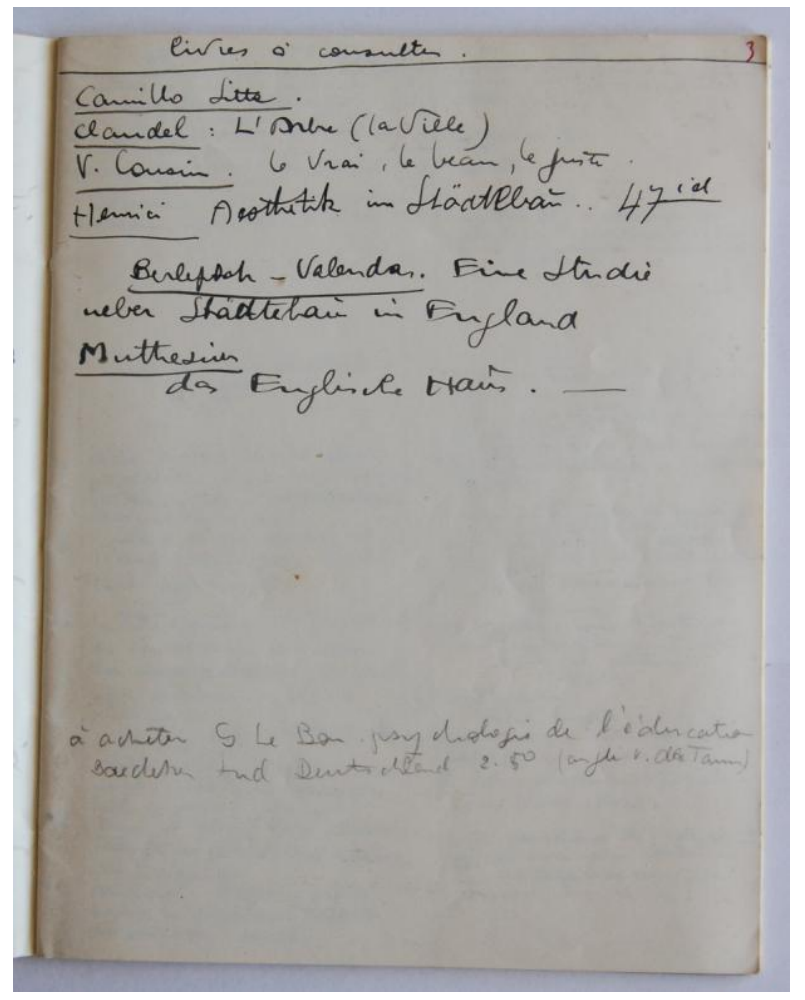

1. "La construction des villes", Cahier C.3, p. 52 (Lcdv 426). Reading list, early April 1910.

The remarkable and specific aspect to focus on for this paper is the consistency with which Jeanneret explored how urban space was generated - space in the sense of enclosure, even volume. It seems that he even 'invented' a new term for this, by using the French term corporalité, an underutilized French word, as synonym for the German word Raum, or space, but in the sense of the spatial enclosure of a chamber. ${ }^{16}$ It may be important to set this notion in comparison to a claim that Kurt Forster made in his groundbreaking analysis of the La RocheJeanneret houses in Paris. Forster says about the La Roche house: "The most conspicuous curvatures, the swelling body of the La Roche gallery and the softly rounded stairwell giving onto the rear terrace, reassert Le Corbusier's explicit distinction between volume and space [highlighted by author]"17. Forster bases this judgement on his combined reading of Purisme, the rappels in Vers une architecture, and Le Corbusier's theory on tools as body extensions, as laid down in L'Architecture décoratif d'aujourd'hui. Pointing at the "membrane-

\footnotetext{
${ }^{14}$ See Schnoor (ed.), La Construction des villes, pp. 615-17.

${ }^{15}$ Städtebau had just recently become a discipline in Germany - the Technische Hochschule Charlottenburg had introduced the first chairs of Städtebau, with Professors Joseph Brix and Felix Genzmer in 1903 and 1904.

${ }^{16}$ Cf. Christoph Schnoor, "Le Raum dans La construction des villes de Le Corbusier. Une traduction aux multiples strates linguistiques et culturelles", in: Traduire l'architecture, ed. Jean-Sébastien Cluzel, Paris 2015.

17 Kurt Forster, "Antiquity and Modernity in the La Roche-Jeanneret Houses of 1923", in K. Michael Hays (ed.). Oppositions. Selected Readings from a Journal for Ideas and Criticism in Architecture 1973-84 (New York: Princeton Architectural Press, 1998), p. 471.
} 
like nature of spatial envelopes" "18, Forster further asserts: "Le Corbusier built this experiential distinction between the organic form of the human body and the geometric structure of spatial abstractions into his architecture. In moving through the house, gesturing into space, or retreating to the 'hidden places' where purely utilitarian equipment modelled on the human body has been installed in compact volumes, one experiences the dialectic opposites of conceptualized space and bodily presence. Space comes to represent abstract totality, equipment the reality of need"19.

If we were to follow Forster's claim, Le Corbusier's notion of space could only be an abstract totality while it was the bodily volumes of curved elements that asserted themselves in space. This dichotomy however overlooks an aspect which lets Le Corbusier's space appear as less of a dichotomy, but instead introduces a tension that cannot be resolved. The fact that the curved volumes contain spaces that seems to have, in themselves, been shaped by the human body who uses them ${ }^{20}$, adds another, a poetic dimension of the space held by walls that is not explained by the notion of the membrane but instead sees the space itself as volume.

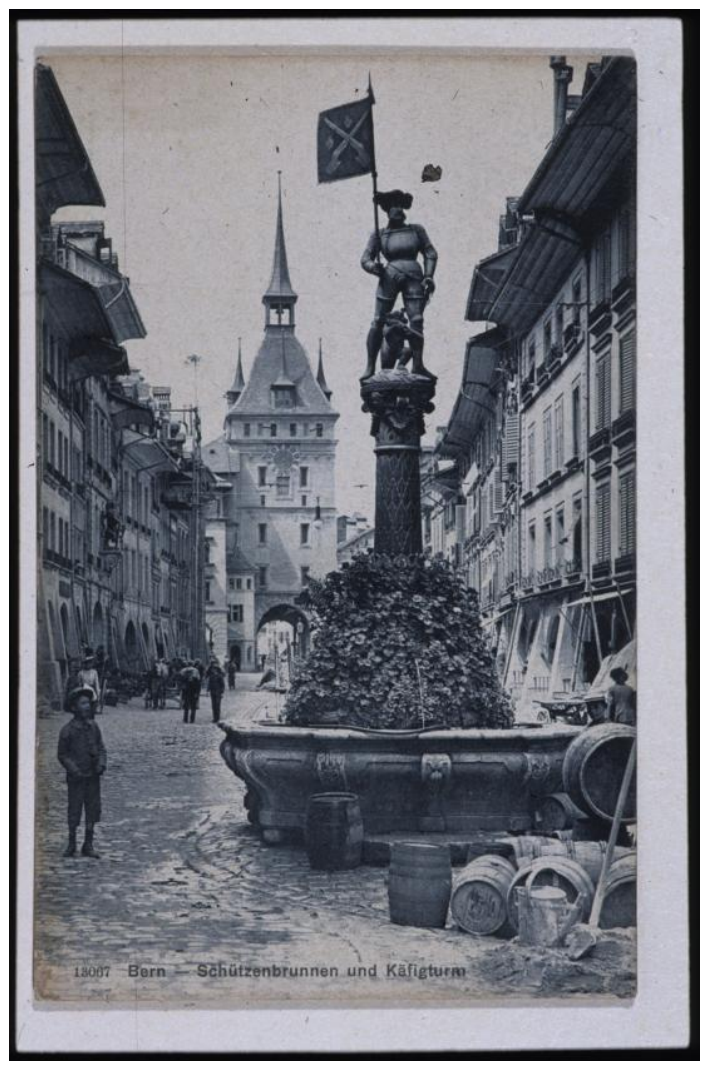

2. Marktgasse in Berne, L5-9-46 FLC

For this to be explained, Le Corbusier must be heard first; in La construction des villes, he analysed urban space generated by streets [Fig. 2], concluding: "We have all experienced the enchanting Marktgasse in Berne, having been through the passageway under the Käfigturm tower; [...]. The beauty of this street is generally attributed to the very edifices which frame it, to the superb fountains which enliven it. This is erroneous. The beauty arises

\footnotetext{
${ }^{18}$ Forster, "Antiquity and Modernity”, p. 471.

${ }^{19}$ Forster, “Antiquity and Modernity", p. 475.

${ }^{20}$ Cf. Christoph Schnoor, "Space and the Body: Concepts of the Corporeal in Le Corbusier's Work", in Kirsten Wagner and Jasper Cepl (eds.), Images of the Body in Architecture. Antropology and Built Space (Berlin: Wasmuth, 2014), pp. 99-130, here pp. 109-113.
} 
from the feeling of perfect volume in the street, and only subsequently - as a result of this - can the façades pay an effective tribute". ${ }^{21}$ Indeed, it is throughout La construction des villes that Le Corbusier uses the term "volume" in such a way that it can be read as synonymous with space. This may have to do with the fact that, inspired by Sitte's approach, Jeanneret very carefully studied what made spaces feel enclosed, which elements added to this condition and how this was perceived by the passer-by, the user of a city.

\subsection{Public urban space as enclosure}

In the general context of Jeanneret's investigation of künstlerischer Städtebau (Camillo Sitte's approach towards urban design that had architectural, artistic intent) it is not surprising that Jeanneret would have studied very carefully the various conditions Sitte discussed that make a public urban space feel spatially enclosed. However, it is remarkable with what persistence Jeanneret extended this search for spatial enclosure to his investigation of streetscapes, indeed of walls of enclosure ("Murs de Clôture"). Even in his excerpts and sketches for the chapter on cemeteries, a sense of spatial enclosure is brought out very strongly - on the one hand through the notion of the wall as enclosing element (Pisa), and on the other hand through plants as creating walls [Fig. 3]. This was fostered by contemporary architects' understanding of the garden as an architectural space, as Jeanneret would see at first hand in Peter Behrens' office. ${ }^{22}$
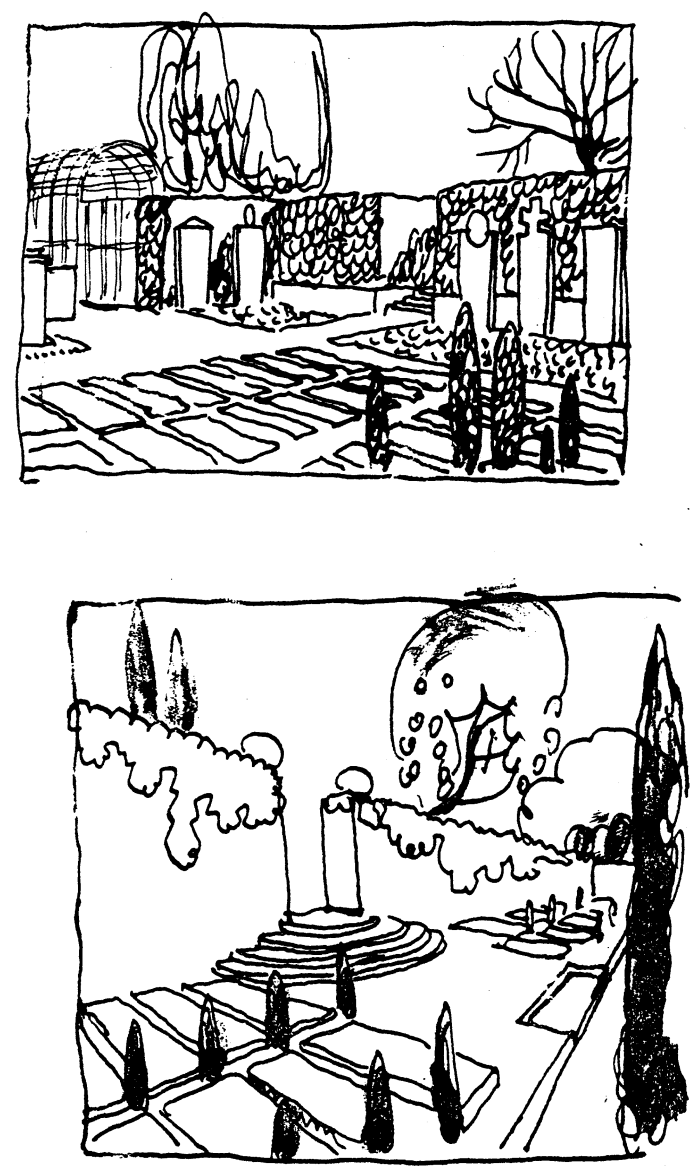

3. "La construction des villes", Cahier C.9, p. 250 (Lcdv 298)

\footnotetext{
${ }^{21}$ Charles-Edouard Jeanneret, "La construction des villes”, Lcdv 104, in Schnoor (ed.), La Construction des villes, p. 302.

${ }^{22}$ Barry Bergdoll, "Das Wesen des Raums bei Mies van der Rohe", in Barry Bergdoll and Terence Riley (eds.), Mies in Berlin (Munich: Prestel, 2001), pp. 66-105.
} 


\subsection{Theory of perception of space - static and in motion}

In terms of this paper's argument, the other crucial element for Le Corbusier's architectural formation is the flâneur's perception of urban space. Although Le Corbusier seems to not have read any of the theories on architectural space that had been developed by art historians just two decades earlier - neither August Schmarsow nor Heinrich Wölfflin are mentioned in his notes - he nevertheless learned about the applications of these theories through the practical aesthetics of architects and art historians. Jeanneret specifically studied writings by architects Karl Henrici and Paul Schultze-Naumburg and by art historian Albert Erich Brinckmann in depth.

Henrici, in his Beiträge zur praktischen Ästhetik im Städtebau ("Contributions to a Practical Aesthetic in City Planning"), laid down rules for the 'correct' design of streetscapes, so as to prevent them from appearing tedious for the passer-by who experienced the city by walking. ${ }^{23}$ Similarly, Paul Schultze-Naumburg, in the volume Der Städtebau, as part of his nine-volume Kulturarbeiten, explored how streetscapes were unfolding in front of the passerby's eye, and through that implicitly formulated the notion of an architectural movie in the flâneur's perception. ${ }^{24}$ Albert Erich Brinckmann, in his work Platz und Monument ("Square and Monument") of 1908 took a slightly different approach. ${ }^{25}$ While he also referenced Sitte's book as a starting point, he used a historical approach to investigate urban squares in Europe throughout history, arguing that the "Raumgefühl",26, the spatial feeling of each epoch, was different and required different architectural responses. He insisted on understanding the human scale in urban design. ${ }^{27}$ Brinckmann placed a strong emphasis on the square of the French kings and thus inspired Jeanneret in turn to research French urban developments of the 1600s and 1700s. It was also Brinckmann's Platz und Monument that introduced Laugier's writings to Jeanneret.

\section{3. "The Illusion of the plan" as continuation and transformation of Le Corbusier's urban studies of 1910}

The argument here is that through all these aspects of understanding the city and its visually and physically experienced elements, Jeanneret was provided with a set of tools of inquiry, with design tools that would enable him to better understand architectural space. This happened to such a degree that during his Voyage d'Orient, he would have found parallel spatial aspects in the buildings he visited to the urban spaces he had studied through books and through personal, physical experience. It is therefore fascinating to read the chapter of Vers une architecture, "The Illusion of the Plan" 28 , that in many ways refers directly back to his Voyage d'Orient, with the knowledge of Jeanneret's reading of Sitte and other Städtebau writers in 1910: it is almost palpable how his reading of urban design literature in combination with his direct visual experience of the Acropolis, Pompeii and Tivoli generated profound insights on the nature of architecture and in the generation of touching architectural space.

\footnotetext{
${ }^{23}$ Karl Henrici, Beiträge zur praktischen Ästhetik im Städtebau (Munich: Callwey, 1904).

${ }^{24}$ Paul Schultze-Naumburg, Der Städtebau. Kulturarbeiten vol. 4 (Munich: Callwey, 1906).

${ }^{25}$ Albert Erich Brinckmann, Platz und Monument. Untersuchungen zur Geschichte und Ästhetitk der Stadtbaukunst in neuerer Zeit (Berlin: Wasmuth, 1908).

${ }^{26}$ Brinckmann, Platz und Monument, p. 153.

${ }^{27}$ Brinckmann, Platz und Monument, passim.

${ }^{28}$ Le Corbusier, "The Illusion of the Plan", in Toward an Architecture, transl. by John Goodman (Los Angeles: Getty, 2008), pp. 213-230, originally published as Vers une Architecture (Paris: Crès, 1923).
} 


\subsection{The garden as an outside room, a piece of architecture}

It seems that the sharp distinction that exists in Le Corbusier's work between the over-scaled urban designs and the often intimate and intricate spatiality of his architectural works is overcome at this very point where he stresses: "Considering the impact of a work of architecture on its site, I will show that here again the outside is always an inside" 29 . With this remark, Le Corbusier brings together the urban space with the space of architecture, and one feels not only reminded of Alberti's sense of the house as a city but also of Hermann Muthesius' remark that the garden is a continuation of the rooms of the house into the outside. Jeanneret had not only read Muthesius' Das englische Haus in 1910, but had translated long passages about the relationship between house and garden into French, of which this sentence seems crucial: "The garden is seen as a continuation of the rooms of the house, almost a series of separate outdoor-rooms, each of which is selfcontained and performs a separate function. Thus the garden extends the house into the midst of nature ${ }^{, 30}$. And while he was taking excerpts from Georges Riat, L'Art des Jardins, a history of gardens that provided him with many poetic images of famous gardens through all times, Jeanneret commented to himself: "I should say that the garden adjoining the house shall not be a reminder of nature but a continuation of rooms, hallways, etc., of sunrooms or rooms of fresh air ${ }^{, 31}$. In fact, some of the excerpts from Georges Riat were in turn citations of Hyppolite Taine's Voyage en Italie, in which Taine describes Italian gardens as pieces of beautiful and serene architecture. In this context Jeanneret also copied an illustration from Riat, entitled "Xyste et Triclinium sous une treille de la maison de Salluste"32, at Pompeii [Fig. 4].

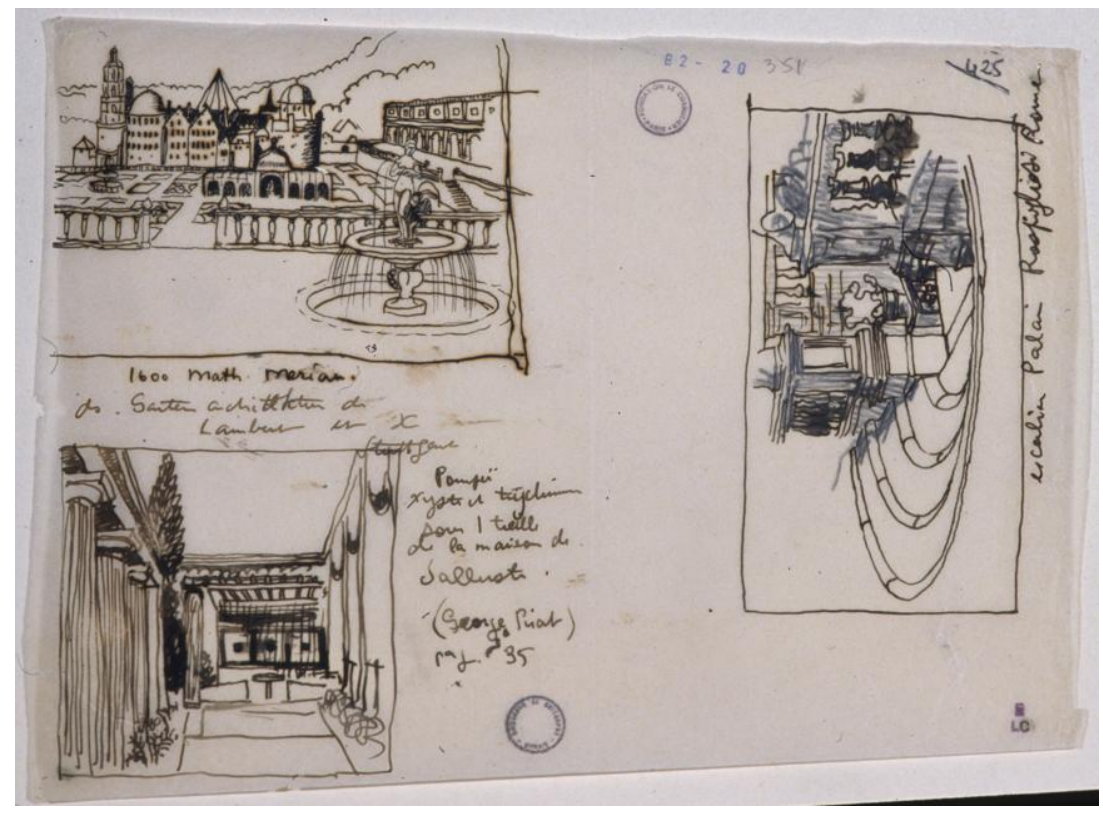

4. B2-20-351 FLC

\footnotetext{
${ }^{29}$ Le Corbusier, "The Illusion of the Plan", p. 216.

${ }^{30}$ Hermann Muthesius, The English House, ed. and introduction by Dennis Sharp, preface by Julius Posener, translated by Janet Seligman (New York: Rizzoli, 1979), 107. The original is Hermann Muthesius, Das englische Haus, Part II, p. 85: "Man erblickt im Garten eine Fortsetzung der Räume des Hauses, gewissermaßen eine Reihe einzelner Außenräume, von denen jeder in sich geschlossen eine gesonderte Bestimmung erfüllt. So erweitert der Garten das Haus in die Natur hinein.”

31 "Dire que le jardin attenant à l'habitation ne doit pas être un rappel de nature, mais une continuation des salles, vestibules etc., des chambres de soleil ou de fraîcheur." Jeanneret, "La construction des villes", Lcdv 246, in Schnoor (ed.), La Construction des villes, p. 406. Translation by author.

${ }^{32}$ B2-20-351 FLC, from Georges Riat, L'Art des Jardins (Paris: L. Henry May, 1900) p. 35.
} 
This very compressed collection of literature on gardens might serve to indicate how, in 1910, Jeanneret had laid the foundation for his own explorations, during his Voyage d'Orient, of Pompeii and its houses, and of the notion, which he would fully embrace in his own architectural projects, that the garden could be, in fact, another room of the house. Such a treatment of the garden is visible in the Pavillon de l'Esprit Nouveau - and in his designs for the Immeuble-villas, in which the garden manifests itself as an integral part of the architecture, as a 'garden of stone ${ }^{, 33}$. An approach to this notion already shows in his first house for his parents, the Maison Blanche in La Chaux-de-Fonds of 1912, in which the garden closely follows inspirations from Schinkel (the pergola), Schultze-Naumburg (for the pavillon at the edge of the garden) and Muthesius - in the way that it is set on a socle or plinth [Fig. 5].

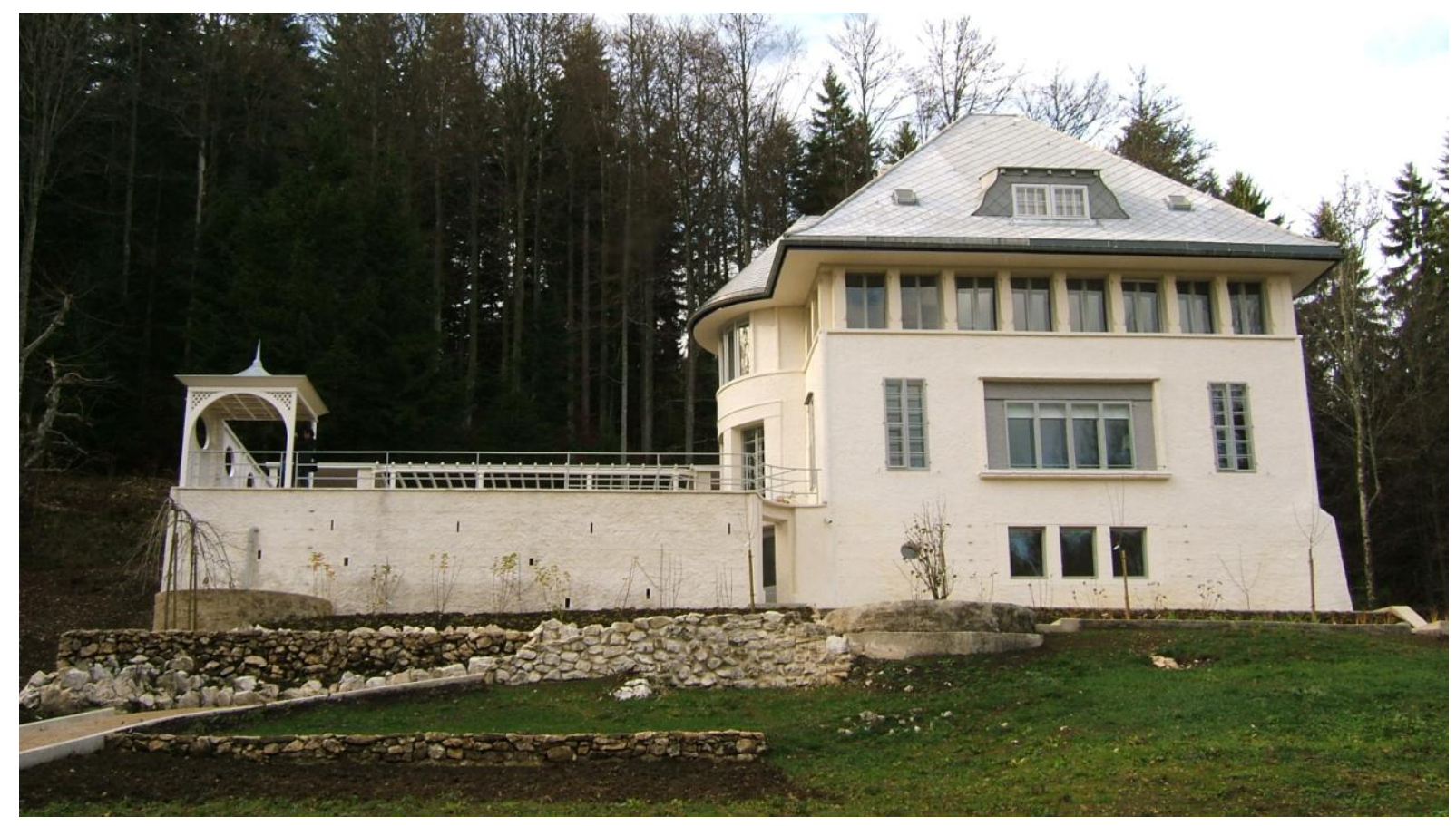

5. Maison Blanche (photo Christoph Schnoor)

\subsection{The admiration of the wall in urban situations and in Pompeian houses}

In the chapter "The Illusion of the Plan", Le Corbusier further asserts: "Architecture has as its goal to make us cheerful or serene. Have respect for walls. The Pompeian does not put holes in his walls; he has devotion for walls, a love for light. Light is intense if it is between walls that reflect it. The man of antiquity made walls, walls that extend and join together to make for still larger walls. Thus he did create volumes, the foundation of architectural sensation, of sensory sensation" ${ }^{34}$. The wall is paid due respect in what forms one of the magnificent discoveries within La construction des villes: a very short chapter that Jeanneret devoted to the idea of the wall in an urban context. He calls this chapter "Murs de Clôture", walls of enclosure, and it is almost

\footnotetext{
${ }^{33}$ See Christoph Schnoor and Claudia Kromrei, "Immeuble-villas between Albert Gessner and Le Corbusier", in Andrew Leach and Alexandra Brown (eds.), OPEN. Proceedings of the 30th Annual Conference of the Society of Architectural Historians, Australia and New Zealand SAHANZ. Griffith University, Gold Coast, Australia. pp. 807-22.

${ }^{34}$ Le Corbusier, "The Illusion of the Plan", p. 220.
} 
entirely based on passages in Paul Schultze-Naumburg's Städtebau. ${ }^{35}$ Schultze-Naumburg praises the beauty of the enclosure and, as a reader, one feels the spatial sense of enclosure as an almost bodily tangible feeling of being held: "The wall is not just a rigid and unyielding enclosure which incidentally is very ugly [...], but it is rather the most noble and beautiful kind of enclosure altogether. Only the wall allows one to carry the sensation

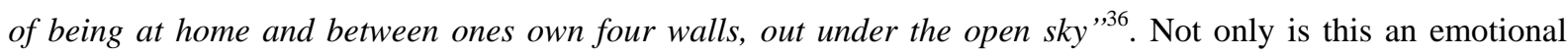
argument for a simple and everyday piece of built structure, but one feels reminded of Jeanneret's note to himself, penned in his notebook on gardens: "I should assert this: for the GARDENS, that they are rooms - in fact, floor, wall and ceiling, and not houses. And that one should create volumes in which one feels inside and not outside oneself ${ }^{, 37}$. This - at its end rather enigmatic - statement makes more sense when read in parallel with Schultz-Naumburg's affirmation of the wall's qualities before: it might be that Jeanneret was aiming at expressing exactly that sensation of feeling 'at home while outside'. Based on Schultze-Naumburg's words and his own experiences from Pisa and Paris, Jeanneret had written in 1910: “A wall is beautiful, not just through its sculptural beauty, but also through the impressions it can evoke. It speaks of comfort, it speaks of delicacy, it speaks of power and of brutality: it is forbidding or it is welcoming; sometimes it holds a mystery. A wall is suggestive of feelings ${ }^{\prime 38}$. Jeanneret praised the wall of the Archives Nationales in Paris as well as the powerful wall around the Cathedral, Baptistery and Cemetery in Pisa, and in particular the wall of the Camposanto Monumentale itself $^{39}$. It even seems that he was ascribing a paradise-like peace to this particular piece of architecture. This does not mean to claim that Jeanneret had only developed a sense of the spatial quality of walls through reading Schultze-Naumburg, as it seems that he had already been aware of them during his first visit to Pisa in 1907. But from the similarity of his words with Schultze-Naumburg's formulations one is tempted to see the latter as having sharpened Jeanneret's sense of the spatial quality of walls.

Judging from Le Corbusier's design 'template' of the Maison Dom-Ino, one might get the impression that Le Corbusier's architecture - at least in the 1920s - was all about horizontality and the free plan, but no more than that. As Max Risselada claimed: "In the work of Le Corbusier, the distance between floors seems no longer important; only by way of stairs and ramps can the vertical dimension be realized". 40 But this is not the case. Risselada's interpretation might be more suitable for many of Mies van der Rohe's spaces. Colin Rowe analysed many of Mies' spaces as what he termed "International Style Space" - a space sandwiched between two horizontal planes, with the specific requirement that the underside of the ceiling be uninterrupted so as to fully convey the smooth sensation of a space sliced horizontally, and extending into the distance ${ }^{41}$. On the other hand,

\footnotetext{
${ }^{35}$ Paul Schultze-Naumburg, Der Städtebau. Kulturarbeiten vol. 4 (Munich: Callwey, 1906).

36 "Die Mauer ist eben nicht bloss eine steife, starre Umwehrung, die im übrigen sehr hässlich [...] ist [...]. Sondern sie ist die edelste und schönste Art der Umwehrung überhaupt. Sie allein ermöglicht es, dass man das heimische Gefühl, zwischen seinen vier Wänden zu sein, auch unter freien Himmel hinausträgt [...]." Paul Schultze-Naumburg, Der Städtebau, Kulturarbeiten vol. 4, 1906/09, p. 429. Translation by author.

37 "Il faudrait bien affirmer ceci: pour JARDINS, c'est que ce sont des chambres, - en effet, plancher, parois et plafond, et non pas des maisons. Et qu'il faut créer des volumes ds lesquels on se trouve dedans et non pas situés hors de soi." Jeanneret, "La construction des villes", Lcdv 244, in Schnoor (ed.), La Construction des villes, p. 405. Translation by author.

38 "Un mur est beau, non seulement de sa beauté plastique, mais aussi des impressions qu'il peut éveiller. Il parle de confort, il parle de délicatesse, il parle de puissance et de brutalité : il est rébarbatif ou il est accueillant ; - il détient le mystère parfois. Un mur est évocateur de sentiments." Jeanneret, "La construction des villes", Lcdv 228, in Schnoor (ed.), La Construction des villes, p. 395. Translation by author.

${ }^{39}$ Jeanneret, "La construction des villes", Lcdv 310, in Schnoor (ed.), La Construction des villes, p. 446-47.

${ }^{40}$ Max Risselada, "Free Plan vs. Free Façade. Villa Savoye and Villa Baizeau revisited," in: Raumplan versus Plan Libre (Rotterdam: 010 Publishers, 2008), p. 85.

${ }^{41}$ Colin Rowe, "Neo- 'Classicism' and Modern Architecture II", in The Mathematics of the Ideal Villa and Other Essays (Cambridge, Mass.: MIT Press, 1976), 143.
} 
in "The Mathematics of the Ideal Villa", Rowe analysed Le Corbusier's space in the Villa Stein/de Monzie as centrifugal but always pushing against walls: "by introducing inversive gestures alongside expansive ones, he again makes simultaneous use of conflicting strategies ${ }^{, 42}$. Through its relentless verticality, the wall - and this is not just the rough stone wall which appears in Le Corbusier's architecture from circa 1930 onwards - is a strong counterpoint to the notion of crisp and clean horizontality. It is for this very reason that the careful establishment of Le Corbusier's appreciation of walls is worth re-considering here. Quite obviously, he did not lose his interest in the vertical boundary of a building but continued to explore the tension between the horizontal and the vertical. For this reason it is so valuable to see the continuation of Le Corbusier's appreciation of the wall from "La construction des villes" through to his modernist buildings of the 1920s and beyond.

\subsection{The axis}

On the surface the central argument of the chapter "The Illusion of the Plan" is of course Le Corbusier's argument that an axis, drawn in plan, may look beautiful but: "In reality, axes are not perceived in bird's-eye views shown in plan on the drawing board, but from the ground, by a man standing erect and looking before him " ${ }^{, 43}$. Thus, Le Corbusier asserts that the experience in space is what counts, rather than the beauty of the drawing. Such a notion he had already explored, in detail, in the introductory chapters of La construction des villes. Inspired by the way in which Städtebau responded to the Genius Loci and was considered in an architectural manner, Jeanneret claimed that throughout history, a good method of planning cities had prevailed: "The first method was design in space. Streets and squares were designed by considering the topography of sites. [...] The planner was a sculptor because he saw in 3 dimensions; he was a poet, because he created landscapes made by human hand, in which beauty, fully impregnated with the laws of Nature, could make staying in cities agreeable and charming" ${ }^{44}$. And he asserts, as the final lines of the chapter: "Beauty of a drawing on a sheet of paper, naive admiration of a fine graphic, this, in short, is the whole error which each page of this study will combat",45.

In "The Illusion of the Plan", Le Corbusier applies his knowledge of urban spaces - both from his reading and from the experience in space - to the House of the Tragic Poet in Pompeii, confirming the subtle qualities of an axis that is present but does not intrude through an overly direct assertion: "Everything relates to an axis but you'd have a hard time drawing a straight line through it. The axis is in the intentions, and the splendour given by the axis extends to the humble things that the latter affects with a skilful gesture (the corridors, the main passage, etc.), through optical illusions. The axis here is not a dry theoretical thing; it links the crucial volumes yet spells them out and differentiates them from one another" ${ }^{\text {,46. }}$

He further points out the difficulty of placing objects directly on axis, saying: "The fountain to the rear is in the corner of the garden. An object placed in the centre of a room often ruins the room since it prevents your placing yourself in the centre of the room and having the axial view; a monument in the centre of a square often ruins

\footnotetext{
${ }^{42}$ Colin Rowe, "The Mathematics of the Ideal Villa", in The Mathematics of the Ideal Villa and Other Essays (Cambridge, Mass.: MIT Press, 1976), 12.

${ }^{43}$ Le Corbusier, "The Illusion of the Plan", p. 221.

${ }^{44}$ Jeanneret, "La construction des villes", Lcdv 43-44, in Schnoor (ed.), La Construction des villes, p. 258. Translation by Kim Sanderson.

${ }^{45}$ Jeanneret, "La construction des villes", Lcdv 46, in Schnoor (ed.), La Construction des villes, p. 259. Translation by Kim Sanderson.

${ }^{46}$ Le Corbusier, "The Illusion of the Plan”, p. 223.
} 
the square and the buildings around it - often, but not always; every such case has its own logic ${ }^{, 47}$. This is Sitte at his finest. In La construction des villes, Jeanneret had most carefully studied and reproduced Sitte's argument for the so-called point mort ${ }^{48}$, the argument that a monument should not be erected in the centre of the square but in the 'dead corner', since this was the space that passers-by could refer to [Fig. 6]. It gave the monument a scale while being out of the way of the traffic. Sitte used the example of Michelangelo's argument to place his David at the corner of the Piazza dei Signoria and not in its middle, and he quoted the Forum in Pompeii as an example $^{49}$.

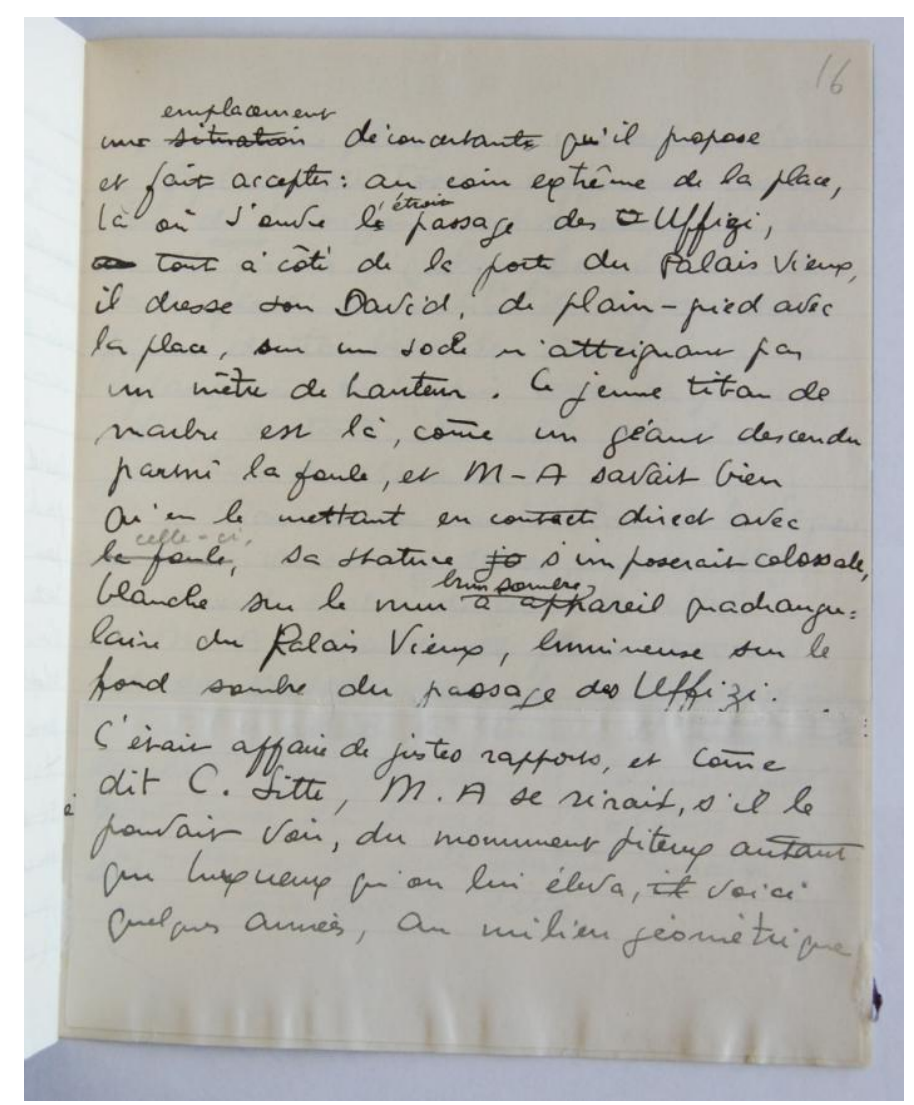

6. "La construction des villes", chapter text on squares (Lcdv 185), explaining Michelangelo's placing of the David sculpture.

To summarize: the Voyage d'Orient substantiated Jeanneret's newly gained - theoretical and experiential knowledge on urban spaces and added further, related aspects of the same topics. Le Corbusier's chapter on "The Illusion of the Plan" acts as another joint between the urban and the architectural space: not just houses figure in it, but also the Forum of Pompeii, which had served as an important argumentative device for Camillo Sitte in his Städte-Bau, and a point that Jeanneret had already picked up in his writings of 1910. Thus it evolves that many of the intellectual investigations begun in 1910 are still present in Vers une architecture, as much as in fact many of his assertions in Vers une architecture are best explained through the link back to the urban design investigations of more than ten years earlier.

\footnotetext{
${ }^{47}$ Le Corbusier, "The Illusion of the Plan", p. 224.

${ }^{48}$ Sitte, Der Städte-Bau, chapter "Das Freihalten der Mitte", pp. 24-37.

${ }^{49}$ Sitte, Der Städte-Bau, pp. 21-23.
} 


\section{Villas La Roche-Jeanneret \& Savoye as realization of urban design principles}

Having established above that in "The Illusion of the Plan", important topics that Jeanneret had investigated and intellectually developed in La construction des villes, had not disappeared at all but had matured, the hypothesis is now taken further via an interpretive look at elements of the houses La Roche-Jeanneret and Villa Savoye.

In his analysis of the Maison La Roche-Jeanneret, Kurt Forster has made us aware of Le Corbusier's active borrowings from antiquity ${ }^{50}$, as an enquiry into architecture on a most fundamental level, as Anthony Vidler put it: "the forms of Greek temples, Roman monuments, and Pompeian houses as illustrated by Le Corbusier in his canonical text Vers une architecture do not refer to any already formulated Humanist tradition. Instead they stand for the origin of 'architecture' itself. That is, they are not so much to be measured and encoded into

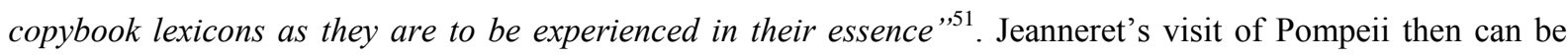
seen as a continuation of his urban studies where, as Leo Schubert observed, "all interiors had been turned into exteriors. [...] The atria, with their fountains and colonnades, became little plazas, and rooms became patios "52. Thus, Pompeii by its very nature may have suggested to Jeanneret a transition between the urban and the architectural spaces.

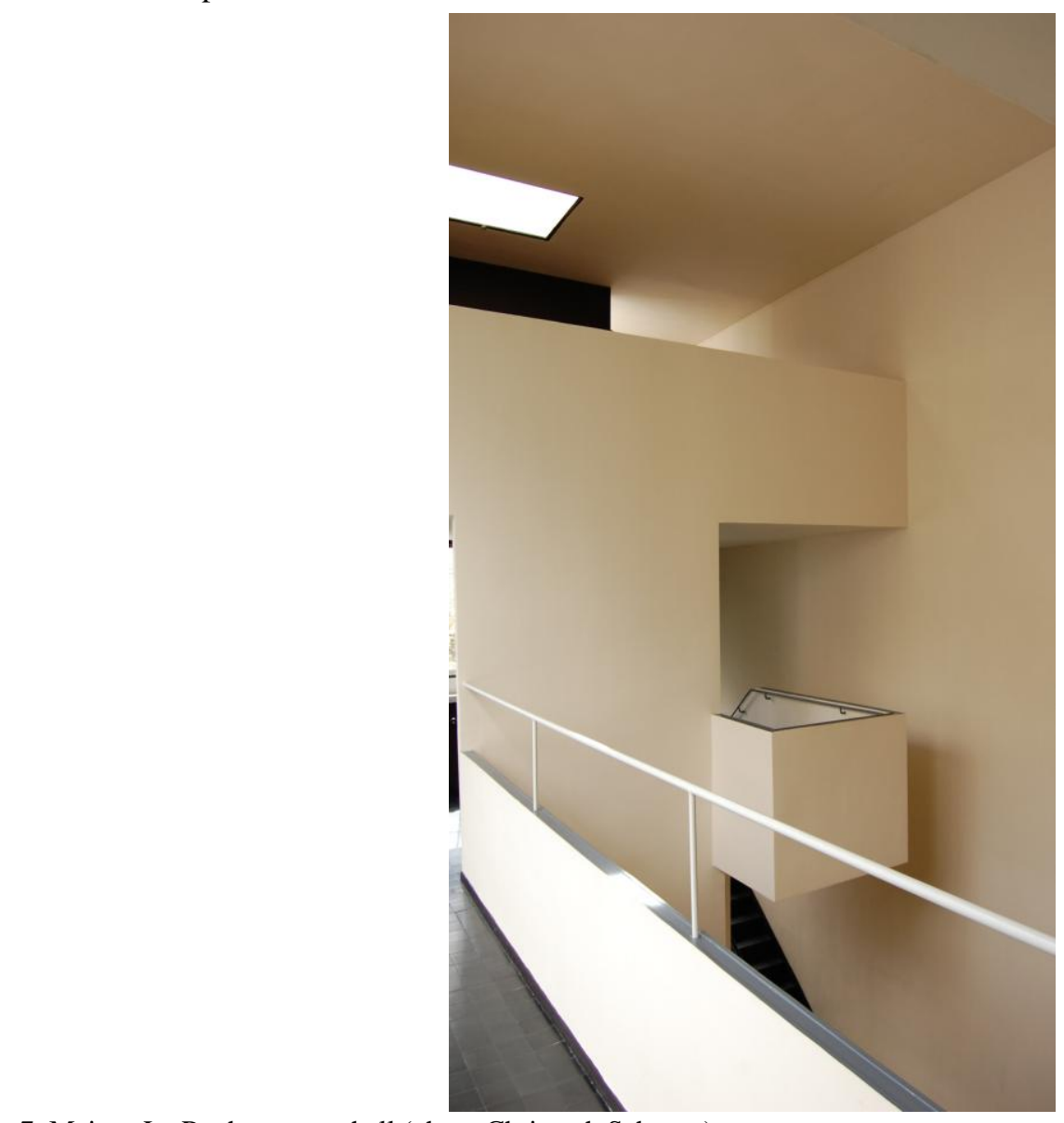

7. Maison La Roche - entry hall (photo Christoph Schnoor)

\footnotetext{
${ }^{50}$ Forster, "Antiquity and Modernity”, pp. 463-85.

${ }^{51}$ Anthony Vidler, "The Abstraction of History", in K. Michael Hays (ed.): Oppositions. Selected Readings from a Journal for Ideas and Criticism in Architecture 1973-84 (New York: Princeton Architectural Press, 1998), p. 461.

${ }^{52}$ Leo Schubert, "Jeanneret, the City, and Photography", in Stanislaus von Moos and Arthur and Rüegg (eds.), Le Corbusier before Le Corbusier (New Haven - London: Yale University Press, 2002), p. 64-65.
} 
Le Corbusier's houses of the 1920s can be read as incorporating elements of the urban design studies, written down in La construction des villes, of 1910. In the Maison La Roche-Jeanneret [Fig. 7], the entry hall is like a public square on several levels. It is a tightly compressed space, it fulfils the client's demands for a social space - in fact it is a space like a theatre or one of the many stage-like public spaces in Venice. The visitor stands on the ground floor and imagines himself holding a glass of champagne while greeting someone who is in conversation with a friend on the first floor. People look down from the library and greet: it is a such a wellcomposed space to celebrate 'seeing and to be seen'. And in this, it feels not like an indoor room but indeed like a public urban space, a space in which the inside is always an outside, to take up and invert Le Corbusier's own phrase from "The Illusion of the Plan": the wall with balcony on the left side of the entrance might as well be the façade of a house - and, as Forster has shown in his analysis, it is almost virtually an outside since the interior balcony is the counterpart to the second balcony outside the gallery.$^{53}$ This is an important point because I would like to assert here that I believe scales, for Le Corbusier, were mutable. Architecture and urban design then are not too distant spheres that cannot intermingle, but as this paper attempts to show, they interchange in $L a$ construction des villes itself, and, for Le Corbusier, experiences from the urban realm are allowed to enter his architecture.

Of course, almost the whole La Roche part of the house is also a promenade architecturale. And while Richard Etlin has already pointed at the link between picturesque urban design and the notion of the promenade, and Bruno Reichlin has delivered an inspiring reading of the promenade based on a comparison with Le Corbusier's purist paintings $^{54}$, it should be emphasized here that Jeanneret's urban design studies of 1910/11 had a lasting influence of the development of the idea of the promenade. As Jeanneret carefully studied Henrici's and Schultze-Naumburg's elaborations on the effect that a well-designed streetscape has on the passer-by, these studies helped him develop the notion of the promenade with ever-changing views.

But the ramp itself takes us back to the matter of the pack-donkey. It is, in fact, Karl Henrici who had put the idea of the pack-donkey into Jeanneret's head in 1910, by suggesting that for humans (!) and beasts of burden (such as the pack-donkey) alike, winding paths uphill were much easier to negotiate and that serpentines were the right choice, rather than continuous gradients. Jeanneret had, in many words, taken up this suggestion and formulated a lengthy passage in his chapter on roads, in which he asked that 'the donkey's lesson should be remembered. In fact, if this beast with its long ears had been in the planners' office, it would have suggested: 'When it comes to streets sloping upwards, my dear planners, consider as much as you can ourselves, the poor beasts condemned to bear very heavy burdens. We do not like your continuous slopes which you draw so very straight ${ }^{, 55}$.

\footnotetext{
${ }^{53}$ Forster, “Antiquity and Modernity”, p. 469.

${ }^{54}$ Richard A. Etlin, Frank Lloyd Wright and Le Corbusier: The Romantic Legacy Manchester and New York: Manchester University Press, 1994), pp. 106-18; Bruno Reichlin, “Jeanneret - Le Corbusier, Painter - Architect". In Eve Blau and Nancy Troy (eds.), Architecture and Cubism (London - Cambridge, Mass.: MIT Press, 1997), pp. 195-218.

55 "La leçon de l'âne est à retenir. En effet, si la bête aux longues oreilles, si elle eût fait partie du bureau du cadastre eût proposé ceci: 'Quand il s'agit dess rues montantes, messieurs les géomètres, pensez pour autant qu'il será posible à nous autres, pauvres bêtes condamnées à tirer des fardeaux bien lourdes. Nous n'aimons pas vos pentes continues que vous tirez si bien droites [...]". Jeanneret, "La construction des villes", Lcdv 117, in Schnoor (ed.), La Construction des villes, pp. 31920. Lcdv 117. Transl. Kim Sanderson.
} 


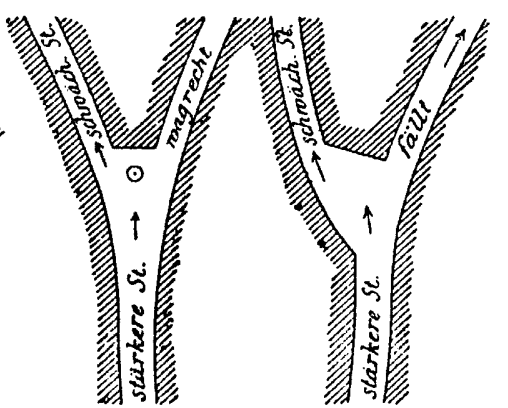

$\Lambda$ bbild. $1-4$.

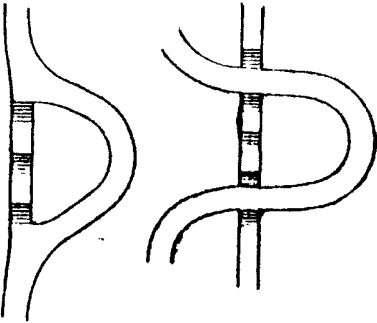

Abbildg. 5 u. 6.

8. Karl Henrici, Beiträge, p. 102-103, figs. 1-6. Figures 5 and 6 indicate the intertwined street and stairs.

In his further explanations on this topic, Henrici propounds how, on sloping sites, paths for pedestrians and streets should be entwined: "... if one has reason and opportunity to design such routes for pedestrians, and interrupts these with rest stops, then [...] the stepped or terraced form runs alongside or intertwines with the hairpin bend. The relevant example is a street designed for traffic which runs up in large bends to the crest of a hill, crossed by a footpath following a shorter line ${ }^{, 56}$. Henrici further demands that the connection between those two motifs be visible: "With such open site, it is important for the overall impression given that the connection between the two motifs, the sinuous route and the steep ramp, steps or terrace, be recognisable [Fig. 8]; lively intersections of the various lines arise, and the impact can be heightened fully by introducing architectural pieces, sculptural or garden ornaments ${ }^{, 57}$. This, as one cannot fail to notice, is exactly what Le Corbusier achieved in the Villa Savoye. Ramp and circular stairs are the two means of vertical transport, the ramp as horizontal and therefore as easy as possible, the stairs as vertical as feasible. The two are placed in close proximity so that the effect of interweaving is very noticeable for the visitor entering the Villa [Fig. 9].

\footnotetext{
56 “...und wenn man Gelegenheit und Veranlassung hat, solche Richtewege für Fussverkehr anzulegen, und diese mit Ruhepunkten unterbricht, dann ergibt sich [...] eine Durchdringung oder Nebeneinander der Treppen- oder Terrassenform mit der Serpentine. Das Vorbild dafür liefert jede Fahrstrasse, die in grossen Windungen zu einer Berghöhe hinaufführt, mit dem Fusspfade, der sie in kurzer Linie durchkreuzt”. Henrici, Beiträge, p. 103-104. Translation by Kim Sanderson.

57 "Bei solchen offenen Anlagen ist es für den Eindruck von Bedeutung, dass man die beiden Motive, das der Serpentine und das der steilen Rampen-, Treppen- oder Terrassenbildung, in ihrem Zusammenhange erkennt; da ergeben sich belebende Überschneidungen der verschiedenartigen Linien, und durch einzuführende Architekturstücke, durch bildnerischen oder gärtnerischen Schmuck lässt sich die Wirkung auf das Höchste steigern.” Henrici, Beiträge, p. 102-103. Translation by Kim Sanderson.
} 


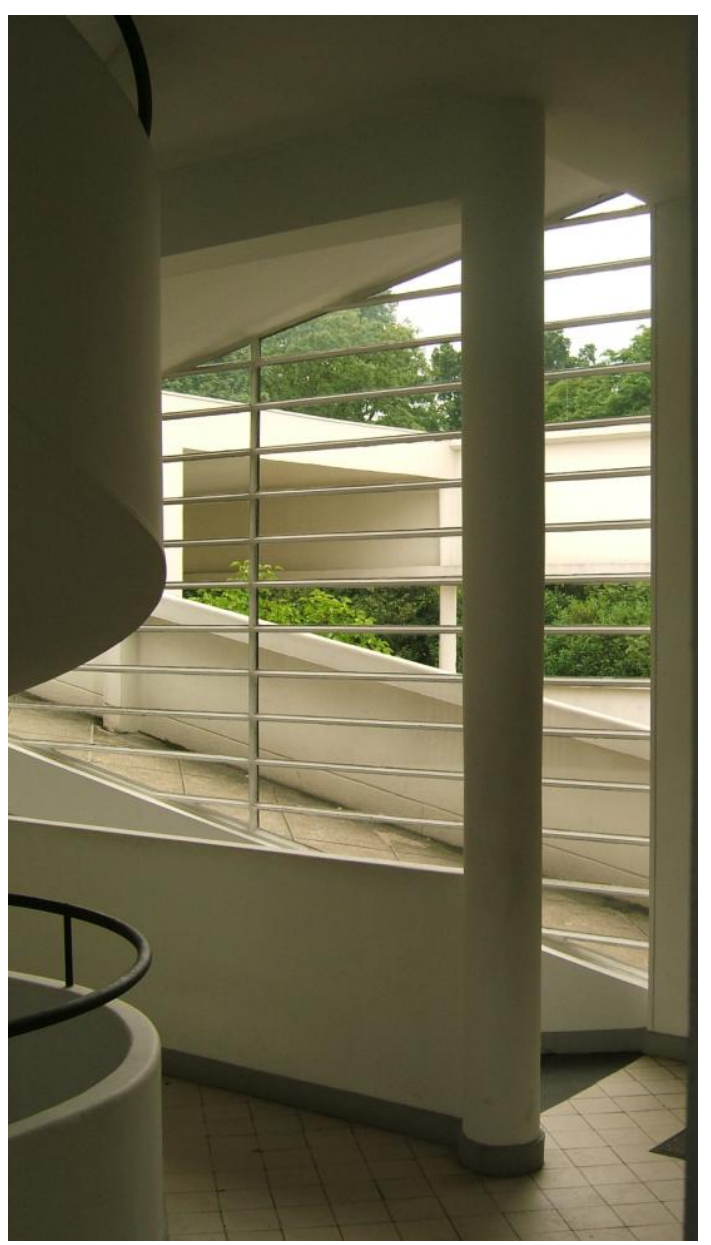

9. Villa Savoye: ramp and stairs (photo Christoph Schnoor)

\section{Conclusion}

By comparing passages from La construction des villes with the chapter "The Illusion of Plans" and selected houses from the 1920s, this paper has attempted to show that Le Corbusier enabled himself to learn, through his urban studies of 1910/11, as much about architecture as he learned about urban design. In fact I believe that it was through his thorough investigation of the qualities of urban space and its manifold conditions that Le Corbusier enabled himself to shape his extraordinary understanding of the many characteristics of architectural space.

\section{Bibliography}

Bergdoll, Barry. "Das Wesen des Raums bei Mies van der Rohe”. In Barry Bergdoll and Terence Riley (eds.). Mies in Berlin. Munich: Prestel, 2001. pp. 66-105.

Brinckmann, Albert Erich. Platz und Monument. Untersuchungen zur Geschichte und Ästhetitk der Stadtbaukunst in neuerer Zeit. Berlin: Wasmuth, 1908.

Emery, Marc Albert Emery. Charles-Edouard Jeanneret, La Construction des villes. Genèse et devenir d'un ouvrage écrit de 1910 à 1915 et laissé inachevé. Lausanne: L:Age d'Homme, 1992.

Etlin, Richard A. Frank Lloyd Wright and Le Corbusier: The Romantic Legacy. Manchester - New York: Manchester University Press, 1994, pp. 106-18. 
Forster, Kurt. “Antiquity and Modernity in the La Roche-Jeanneret Houses of 1923”. In K. Michael Hays (ed.). Oppositions. Selected Readings from a Journal for Ideas and Criticism in Architecture 1973-84. New York: Princeton Architectural Press, 1998. pp. 463-85.

Gurlitt, Cornelius. Handbuch des Städtebaues. Berlin: Architekturverlag Der Zirkel, 1920.

Henrici, Karl. Beiträge zur praktischen Ästhetik im Städtebau. Munich: Callwey, 1904.

L'eplattenier, Charles. "L'esthétique des villes". In [Résumé de l'intervention de Charles L'Eplattenier à l'] Assemblée générale des délégués de l'Union des villes suisses réunis à la Chaux-de-Fonds à l'Hôtel de Ville, les 24 et 25 septembre 1910, Compte-rendu des délibérations de l'assemblée générale des délégués de l'union des villes suisses, 1910 ; Beilage zum schweizerischen Zentralblatt für Staats- und Gemeinde-Verwaltung no. 11, 1910. pp. 24-31.

Le Corbusier. "The Illusion of the Plan". Toward an Architecture, transl. by John Goodman. Los Angeles: Getty, 2008, pp. 213-230. Originally published as Vers une Architecture. Paris: Crès, 1923.The first version of this text: Le Corbusier-Saugnier, “Architecture II, L’Illusion des plans”, in Esprit Nouveau, no. 15, February 1922. pp. $1767-80$.

Le Corbusier. The City of To-Morrow and its Planning. Transl. Frederick Etchells. New York: Parson and Clarke, 1929. Originally published as Urbanisme. Paris: Crès, 1925.

MuthesiuS, Hermann. The English House. Dennis Sharp, ed. and introduction, preface by Julius Posener, translated by Janet Seligman. New York: Rizzoli, 1979. Originally published as Das englische Haus. Entwicklung, Bedingungen, Anlage, Aufbau, Einrichtung und Innenraum. Berlin: Wasmuth, 1904-11.

Reichlin, Bruno. "Jeanneret - Le Corbusier, Painter - Architect". In Blau, Eve, and Troy, Nancy (eds.). Architecture and Cubism. London - Cambridge, Mass.: MIT Press, 1997. pp. 195-218.

Riat, Georges. L'Art des Jardins. Paris: L. Henry May, 1900.

Risselada, Max. "Free Plan vs. Free Façade. Villa Savoye and Villa Baizeau revisited”. In Max Risselada (ed.). Raumplan versus Plan Libre. Rotterdam: 010 Publishers, 2008. pp. 84-94.

Rowe, Colin. The Mathematics of the Ideal Villa. Cambridge, Mass.: MIT Press, 1976.

Schnoor, Christoph (ed.). La Construction des villes. Le Corbusiers erstes städtebauliches Traktat von 1910/11. Zurich: gta, 2008.

Schnoor, Christoph. "Le Raum dans La construction des villes de Le Corbusier. Une traduction aux multiples strates linguistiques et culturelles”. In Jean-Sébastien Cluzel (ed.). Traduire l'architecture, Paris 2015. pp. 12029.

Schnoor, Christoph. "Space and the Body: Concepts of the Corporeal in Le Corbusier's Work". In Kirsten Wagner and Jasper Cepl (eds.). Images of the Body in Architecture. Antropology and Built Space. Berlin: Wasmuth, 2014. pp. 99-130.

Schnoor, Christoph; Kromrei, Claudia. "Immeuble-villas between Albert Gessner and Le Corbusier". In Leach, Andrew and Brown, Alexandra (eds.). OPEN. Proceedings of the 30th Annual Conference of the Society of Architectural Historians, Australia and New Zealand SAHANZ. Griffith University, Gold Coast, Australia. pp. 807-22.

Schubert, Leo. "Jeanneret, the City, and Photography". In von Moos, Stanislaus, and Rüegg, Arthur (eds.). Le Corbusier before Le Corbusier. New Haven - London: Yale University Press, 2002. pp. 55-67.

Schultze-Naumburg, Paul. Der Städtebau. Kulturarbeiten, vol. 4. Munich: Callwey, 1906.

Sitte, Camillo. City Planning According to Artistic Principles. Transl. George Collins and Christiane Crasemann-Collins. New York: Random House, 1965.

Sitte, Camillo. Der Städte-Bau nach seinen künstlerischen Grundsätzen. Vienna: Graeser, 1889. 
Vidler, Anthony. "The Abstraction of History". In K. Michael Hays (ed.). Oppositions. Selected Readings from a Journal for Ideas and Criticism in Architecture 1973-84. New York: Princeton Architectural Press, 1998. p. 461.

von Moos, Stanislaus. "Vorwort. Im Steinbruch der Vormoderne". In Schnoor, Christoph (ed.). La Construction des villes. Le Corbusiers erstes städtebauliches Traktat von 1910/11. Zurich: gta, 2008. pp. 7-13. 